\title{
The Cultural Politics of WMD Terrorism in Post-Cold War America
}

\author{
Harold Williford
}

\section{Synopsis}

This paper analyzes the prehistory of the War on Terror to explore how the meanings counterterrorists attributed to "terrorism" in the 1990s. A Tom Clancy novel, Rainbow Six, read in the context American cultural shifts in the 1990s surrounding capitalism, technology, globalization, and gender, reveal a counterterrorist fantast of mirroring terrorist dissociation from state institutions to engage in extralegal practices. These tactics range from breaking international law to torture, anticipating the War on Terror. The paper concludes with a consideration of the possibility that 9/11 may have slipped into a pre-existing cultural narrative rather than starting a new one.

\section{Biography}

Harold Williford is currently a J.D. candidate at New York University School of Law. He received a B.A. in Political Science and French from Northwestern University in 2010. The following paper is based on his honors thesis in Political Sicence, which was written under the direction of Professor Bonnie Honig.

\section{Essay}

After the terrorist attacks of September $11^{\text {th }}, 2001$, a perception developed that the events were a shock to the American political consciousness, perhaps summed up by one assertion that "most Americans had no narrative with which to anticipate, and in that sense psychologically prepare for, what actually took place" (Lifton 160). Audrey Kurth Cronin recently critiqued "the ahistorical and amnesiac approach to global terrorism that prevailed in the post-9/11 era" and Judith Butler decried the attitude that "there is no relevant prehistory to the events of September $11^{\text {th" }}$ (Cronin 134; Butler 6). They refer to, respectively the international political conditions and history of imperialism that provide context for the rise of al-Qa'ida. While valuable, such arguments address only part of the historical framing of September $11^{\text {th }}$. Jean Baudrillard saw complementary continuities with popular American disaster and war films and (in)famously claimed, "we can say they did it, but we wished for it" (Baudrillard 5). While it would be difficult to access his sweeping claim about fantasy and desire, his observation demands an inquiry into the continuities within American counterterrorism itself. Post-Cold War representations and analyses of terrorism and violence indicate America may have been predisposed and poised to respond to September $11^{\text {th }}$ with the War on Terror and its attendant questionable extralegal practices.

Several popular fictional works from the 1990s confirm Baudrillard's core claim that the image of the destruction of the Twin Towers was not new. The 1996 
blockbuster Independence Day depicts the collapse of the Empire State Building in an accelerated version of the events of September $11^{\text {th }}$. Meanwhile, Tom Clancy's 1994 novel, Debt of Honor, concludes with a Japanese pilot crashing an airplane into the U.S. Capitol Building. Where Debt of Honor looks back to kamikaze pilots in World War II, another Tom Clancy novel, the 1998 bestseller Rainbow Six, looks forward as it recounts a tale of terrorists with apocalyptic aspirations. Rainbow Six functions as a nexus of counterterrorism and American culture in the 1990s that sutures diverse issues, from capitalism and multinational corporations to reproduction and gender politics, with terrorism. As military and cultural questions unfold and interact in this elaborately plotted lengthy "techno-thriller," Rainbow Six unintentionally reveals that a shift in counterterrorist culture occurred before September $11^{\text {th }}, 2001$.

The ahistoricity of American policy analysts' representation of post-Cold War terrorism indicates that this shift happened with the fall of the Berlin Wall. In the 1980s, Clare Sterling's portrayal of terrorism in The Terrorist Network as a symptom of Communism, with terrorist groups as Soviet surrogates in a web controlled by Moscow, shaped how the Reagan administration understood terrorism (Gibson 270). After the collapse of the Soviet Union, national security analysts trumpeted the development of "new" terrorism (Cameron 162; Deutch 11; Laqueur 32). Without Moscow to control them, terrorists were now "less predictable" and more likely to use nuclear, chemical or biological weapons, collectively known as "weapons of mass destruction" (WMD) (Rose 134). One neoconservative analyst confidently claimed, "Some day, some one will use a nuclear bomb" and "millions will be killed" (Lodal 132). In testimony before a Senate subcommittee, an expert asserted, "the threat of terrorist use of [WMD] has never been greater; and at the same time, it is never going to be less than it is right now" (Cameron 2). One author concluded a book on nuclear terrorism crediting "the current psychodynamics of terrorist groups" and "the nature of terrorism in the 1990s" for the increase in the threat of WMD terrorism (Id. 162). Spending on WMD counterterrorism increased from negligible amounts to $\$ 1.5$ billion (Falkenrath 147). American counterterrorists appear to have forgotten these developments once the War on Terror began.

That forgetfulness forms only one part of a pattern of American cultural amnesia where terrorism is concerned. The portrayal of the "new" post-Cold War terrorism could not be further from historical reality. In 1946, a Jewish extremist group had attempted to poison thousands of German prisoners of war at Nuremburg with arsenic, a chemical weapon, and sought to use WMD to kill up to six million more former Nazis (Sprinzak and Sprinzak 17). The Rajneeshees, a religious cult without connection to Moscow, committed the only "successful" bioterrorist attack in 1984 (Carus 115) while, around the same time, a Christian millenarian group stockpiled cyanide in Arkansas with plans to poison the water supply of a major city (Hamm 151). Written in 1978, the white supremacist novel by William L. Pierce under the nom de plume Andrew MacDonald, The Turner Diaries, concludes with a suicide bomber crashing a plane loaded with a nuclear weapon into the Pentagon. Many members of the loose network of American right wing militant groups were radicalized by fears of communism, not by Moscow (Flynn and Gerhardt 14). WMD and diverse ideological objectives were far from "new" elements of terrorism. If history contradicts the "new" terrorism narrative, analyzing its contemporaneous cultural and political roots might provide an explanation for how WMD terrorism became the new "black" in national security fashion. 
The concept of terrorism could fulfill the need for an enemy created by the collapse of the Soviet Union and, with it, Cold War binarism. Where Americans had been able to "cast themselves as the righteous heroes of a morality play performed on world history's stage" by seeing their Soviet opponents as "literal incarnations of human evil (the devil)," the fall of the Berlin Wall opened a world of multipolar politics, perceived as anarchy by budding counterterrorists, in which America's role and moral credibility were less clear (Gibson 289; Sherry 438). The grandiose and global threat of WMD terrorism had the potential to fill a post-Cold War 'demon gap.' The mutable meaning of terrorism rendered it particularly suitable for this function.

Terrorism, as a word, lacks a stable definition, and meanings are often attributed to it based on the speaker's agenda (Hoffman 23). Meanwhile, those described as terrorists often reject the label and seek to apply it to their opponents. Definitions of terrorism have differed amongst government agencies within America alone (Id. 39). The cacophonous debate, while functionally problematic, manifests the cultural and political forces that gathered loosely related concepts under the umbrella of the many meanings of "terrorism." Embracing the instability of "terrorism" reveals the corresponding instability of "counterterrorism." As the counterterrorist defines and delegitimizes the terrorist, he simultaneously defines and legitimizes his own identity. Counterterrorist representations of terrorism operate in this dynamic, where even as they may fail to describe actual non-state militants, they ultimately reveal the counterterrorist's own priorities and anxieties.

Political theorist Michael Rogin's model of countersubversive psychology provides a framework for understanding the relationship between counterterrorist subject and his - constructed - terrorist opponent. Perhaps based on an actual phenomenon, as with the case of WMD terrorism, the subject, or "countersubversive" embellishes and transforms the opponent into the "subversive" or "alien" (Rogin, Ronald Reagan 237). Rogin provocatively posits that the countersubversive conceptualizes the opponent in a way that permits him to engage in forbidden behaviors, fulfilling a repressed desire to mirror the countersubversive (Id.). In texts created by twentieth century American countersubversives, "frenzied doubling... reveal[s] the connections" to the subversive that countersubversives tried to conceal (Id. 10). The Cold War is replete with examples of this dynamic. The threat of Soviet nuclear missiles became a justification for Americans to maintain tens of thousands of nuclear warheads (Franklin 52). Similarly, a perceived need to preserve American freedom from Communist oppression permitted the rapid expansion of government surveillance of Americans (Rogin, Ronald Reagan 258). Rogin prophetically predicted in 1987 that the "theory of international terrorism encapsulates and brings up to date the entire history of American countersubversion" (Rogin, Ronald Reagan 80). Analysis of how terrorism interacted with and threatened property, national identity, family and personal identity, four elements about which American countersubversives have been historically anxious (Rogin, Ronald Reagan 68), illustrates the WMD-wielding terrorist began to function as a "demon" right after the Cold War. The element of mirroring in Rogin's theory further provides a framework for understanding particularly eerie similarities between "terrorist" and American "counterterrorist" practices.

Counterterrorist discourse from the 1990s indicates that capitalism's "victory" in the Cold War rendered private ownership and the free market problematic for national 
security. During the Cold War, the American military had led technological development from which the private sector benefited, but in the 1990s this "spinoff" reversed, putting the military in a position of reliance (Sherry 403). Meanwhile, high salaries in private sectors appeared to draw highly qualified individuals away from government jobs, as the end of the Cold War removed a normative imperative toward public service (Oehler 143). Abroad, the chaotic politics of post-Soviet Russia struck Americans as the perfect storm for a black market for nuclear weapons, in which free market incentives would drive ex-Soviet scientists to sell "loose nukes" to terrorists (Cameron 4). A passage in Tom Clancy's 1998 bestseller Rainbow Six sums up this shift. A fictional expert describes a "good terrorist" as a "businessman whose business is killing people to make a political point... almost like advertising" (Clancy 87 ). The incongruity of this image of a terrorist as a calculating businessman with the 1990s hysteria about destructive ideological madmen illustrates that the concept of terrorism functioned as object upon which Americans could work through deeper concerns.

As Clancy weaves conjectured threats posed by the free market into an apocalyptic fantasy in Rainbow Six, a general anxiety about non-state organizations, including but not limited to terrorists, emerges. The central villain of Rainbow Six is a biotech firm, run by environmental extremists. These extremists genetically modify the Ebola virus to render it an unimaginably potent biological weapon and plan to spread it at the Olympic Games. They intend to exterminate the human species, save themselves. Confronted with this threat, one of Clancy's counterterrorists meditates on how "the changing technological world" that has "given immense power to relatively small organizations" (Clancy 860). Further staging anxieties about the free market, a former FBI agent turned private consultant is a key terrorist mastermind. Confronted with non-state "foreign policy," the hero wonders, "when did they [corporations] begin to think they could play games at this level [that of the nation-state]?" (Id.). Most disturbingly, while "Governments were selected, by and large, by their citizens," corporations "answered-if they did so at all-to their shareholders" (Id). Clancy's fictional corporation replaces Sterling's idea of Moscow and positions itself at the center of a web of terrorist groups to carry out its diabolical plan. Non-state threats, epitomized by Clancy's blending of terrorism and corporation, had stepped into the Soviet demon's shoes.

The "new" terrorist provides the foundation for enactment of a counterterrorist fantasy of mirroring non-state threats. Clancy's American heroes lead an inter-state counterterrorist team, which includes French, German, British and Israeli members alongside a large contingent of Americans, transcending nation-state borders and identities. The American leader believes that if "people realize what a bio-tech company can do if it wants" the result would be "global panic," which matches another hero's conclusion that "in this New World Order things had little in the way of controls at all, and that was something somebody should think about" (Clancy 858,860 ). The resulting strategy, however, is to toss aside transparent governance to avoid publicity (858). Already a "blacker than black" operation, known only to a handful of elite officials, the counterterrorists pursue a range of extralegal strategies, including entering Brazilian airspace in violation of international law (explicitly noted in the narrative), entering America without getting their passport stamped-a masochistic violation of America's own borders-and extrajudicial punishment $(850,894,800)$. The counterterrorist team 
is based in England, because of the "very cordial relationship" between U.K. special forces and British Airways, a blending of corporation and counterterrorists that permits the heroes to fly unnoticed on civilian airplanes-similar to the tactics of modern terrorists (27). Employment of private organizations came to fruition in the War on Terror, exemplified by Blackwater's provision of private security in Afghanistan and Iraq and Jeppesen Dataplan's purported provision of air transport to the CIA extraordinary rendition program. Lack of democratic accountability and absence of effective oversight is as much of an element of counterterrorist organization as a part of the theorized nonstate enemy.

The importance of mobility, another key factor in counterterrorist politics, reveals the deterritorialization of internationalism that came with the shift to non-statism. Clancy's counterterrorists' ability to respond to terrorist attacks anywhere in the world reflects an early proposal for global surgical counterstrike ability as a core counterterrorist national security policy (Rosenbaum 159). Such mobility responds to concerns expressed by then-National Security Advisor Sandy Berger in 2000, that "the transnational network of terror groups" is particularly troubling" because "they are loosely connected" and "cannot be extinguished with one stroke" (36-37). Meanwhile, the "large number of vulnerable U.S. targets abroad allows terrorists to achieve dramatic results without having to penetrate America's borders" (Simon 109). The "pervasive force" of globalization brought multinational corporations and easy international transit, making borders increasingly meaningless.

The departure from physical geography changed the ontology of conflict. Adriana Cavarero draws on Carl Schmitt's Theory of the Partisan to explain how the "partisan who has abandoned the tellurian dimension" introduced "a new type of war in which the global space of combat is characterized by 'pure means of destruction,' in other words 'weapons of absolute annihilation [that] require an absolute enemy lest they should be absolutely inhuman"' (Cavarero 69). The abandonment of "tellurian" warfare arguably begins with airplanes, which are able to destroy nations with nuclear weapons without an army ever setting foot on the country's soil. ${ }^{1}$ The disappearance of the Soviet Union and subsequent focus on terrorism removed the last semblance of geography.

American analysts conjectured that terrorists, without territory against which retaliation could be effected, would not be dissuaded from using WMD by the logic of mutually assured destruction ("MAD"), which had been the stabilizing force in the Cold War nuclear standoff (Tucker 267). Some analysts attempted an awkward transfer of the logic of MAD to the post-Cold War world with proposals of counterstrikes against states who aid terrorists (Lodal 30). More difficult was the repressed feeling that America now acted as a non-tellurian partisan.

WMD terrorism intervened in post-Cold War discomfort as the image of a force more transgressive than American non-statism. Terrorism is already "unconventional" violence—significantly implying the existence of "conventional" violence—but WMD terrorism breaks another "taboo." ${ }^{2}$ The second transgression puts terrorists on the scale of Schmitt's "absolute enemy," which "makes it possible to dehumanize [them] and see [them] as a morally abject criminal[s]" so that "those who annihilate [them] 'are [not] themselves criminal and inhuman'" (Cavarero 69). Understanding WMD terrorism as a specific manifestation of the dehumanized absolutely destructive non-tellurian partisan 
reveals the connections between Rainbow Six and another fixture of America in the 1990s, the 1996 alien-invasion blockbuster Independence Day.

Read together, Independence Day and Rainbow Six reveal how concerns about American identity interact with the image of WMD terrorism. As both alien and terrorist are disconnected from geography, their similar functions as non-state threats is summarized by how the semantics of "extraterrestrial" and "extra-territorial" collapse into "non-tellurian." In addition to wielding WMD and being highly mobile, the aliens further share the key characteristic of randomness with terrorists. The aliens in Independence Day do not specifically target humanity, but merely intend to exploit Earth's resources and then move on. While their nomadic civilization underscores the prominence of nonstatism, their unexpected invasion on a sunny summer day presages September $11^{\text {th }}$, 2001. Cavarero explains that randomness provides the essential horrifying element of contemporary terrorism because it negates the identity of the victim (Cavarero 75-76). Terrorism commits ontological violence as it turns a someone into an "interchangeable and exemplary" anyone (Cavarero 76). To acknowledge the terrorist threat is to accept having been "degraded... from singular being to random being" (Id.). Where Cold War binarism reinforced American exceptionalism, random terrorism undermines the specificity of American identity.

WMD terrorism, portrayed as threatening worldwide destruction, enabled the American counterterrorist to reframe the problematic anyone as everyone. Both Rainbow Six and Independence Day stage threats of extinction, which facilitates the enactment of a fantasy of uniting humanity against the dehumanized enemy, respectively environmental extremists who hate their own species and unfeeling aliens. Ever since the black-and-white morality of World War II produced a euphoric, but transient, unity in America, American culture has exhibited a desire to reproduce that unity (Sherry 88, 498). Counterterrorist politics, however, has the more ambitious desire of achieving global unity in the political space opened by the decreasing importance of geographical borders. Clinton administration officials and neoconservatives argued for the inclusion of China and Russia in comprehensive international coalitions in the context of counterterrorism (Berger 27), while politicians celebrated the number of participants in the Gulf War coalition (Sherry 471). Rainbow Six picks up this theme with its international team, but Independence Day truly carries out the fantasy as the Americans not only include Russia and Japan in the counterattack against the aliens, but the Israelis and Iraqis also come together under Anglo-American leadership in a replay of colonial power structures, which hints at the disturbing nature of the unity.

The unity envisioned by counterterrorist politics commits the same ontological crime as terrorism. Ronald Reagan wondered aloud in 1988 about, in case of a threat from "another planet" whether humans would "find that we didn't have any differences between us at all, we were all human beings, citizens of the world, and wouldn't we come together to fight that particular threat?" (Rogin, Independence Day, 8).

Independence Day stages this exact fantasy as a worldwide counterattack and then develops it in the Hollywood president's climactic speech. Channeling Reagan, he claims, "we can't be consumed by our petty differences anymore." The counterterrorist dream, at its core, is based on the obliteration of difference and reduction of individuals to mere members of the human species. American counterterrorism could then inscribe American identity on this blank slate. 
American nationalism transcended state borders in the 1990s. International institution building became valuable because the U.S. could act as a "gatekeeper," forcing other nations to conform to its values (Berger 24, 27). Analysts urged coalition building for counterterrorism (Lodal 128), and Rainbow Six focuses on U.S. leadership of an interstate group the other members of which are measured against standards set by the Americans. It is Independence Day, however, that executes the fantasy to completion. The successful counterattack takes place on July $4^{\text {th }}$, which allows the Hollywood president to claim,

should we win the day, the $4^{\text {th }}$ of July will no longer be known as an American holiday, but as the day when the world declared in one voice, we will not go quietly into the night, we will not vanish without a fight. We're going to live on, we're going to survive. Today we celebrate our independence day!

Forgetting "petty differences" becomes imposition of American identity on the world, celebrated at the end with missiles turning into a patriotic display of fireworks. The opportunity for remaking the world in America's image only comes through the masochistic fantasy of millions of people dying in fiery WMD. The tone of unmitigated triumph at the conclusion of the movie is only possible because the victims are perfectly interchangeable with the survivors. As long as a reproducing population survived, humanity is saved.

The importance of perpetuation of the human species that defines WMD counterterrorism lays bare the logic of nationalism divorced from the state. The Hollywood president attempts to cast the battle against the aliens as the inheritor of the American Revolution with the claim that they "will once again be fighting for freedom." The parallel breaks down, however, as he elaborates, "Not from tyranny, oppression or persecution, but from annihilation." Annihilation, intuitively as in the film, is an event, not a political condition. The connection between nationalism and reproduction explains the reduction of counterterrorist politics to survivalism. Jacqueline Stevens argues that birthright membership societies are a form of reproduction, born of masculine womb envy, which intervene with "political practices that assume the same ontological status as maternity" (Stevens 161). Birthright citizenship becomes a way to perpetuate national identity. Counterterrorist appropriation of political reproduction through its focus on survival of the species severs the hyphen between nation and state, as it seeks to perpetuate American national identity outside the structures of the state while appointing the counterterrorist the guardian of humanity.

Marriage and reproductive politics in counterterrorist fantasy simultaneously recreate patriarchal dominance and foreclose avenues of women's independence. Rainbow Six foregrounds reproduction through the character of Patsy Chavez, wife of one of the counterterrorist heroes and daughter of their leader. Pregnant for nearly the entire novel, whenever she appears, Clancy notes her pregnancy in some fashion. The male counterterrorists consider it their "self-assigned job" to ensure that their wives do not fear for their safety (Clancy 7 ). This patriarchal protection is put into action when a group of terrorists attempt to hold Patsy and her mother, the counterterrorist leader's wife, hostage at a hospital and the counterterrorists heroically rescue them from the 
"baby-killer[s]" or "woman killer[s]" (662). During this scene the latter group's emotions reveal that the counterterrorist team has replaced the state in that the two women are "family for all of them" and lives that "belong" to the male counterterrorists (603). Independence Day also stages a patriarchal pageant when a pilot marries a single mother, who previously worked as an exotic dancer, resolving the tension created by independent feminine sexuality and maternity. Non-state familial politics brings women to the non-state frontier, where the implosion of geography allows patriarchal politics to close the opening for female empowerment originally created by the departure of men for Europe in World War II, resolving Cold War masculine anxieties encapsulated in "domestic ideology" (May 215). Independence Day punishes female attempts at independence. When the First Lady stays in Los Angeles to imitate her husband's bravery, she dies as a result, admitting on her deathbed that she should have listened to her husband's command that she evacuate sooner. The antifeminism of the moment overwhelms, particularly since the President did not leave Washington, D.C., until the exact same moment - and he had their daughter with him. This brand of patriarchal politics surged in popularity following September $11^{\text {th }}$, as documented by Susan Faludi in The Terror Dream, including predictions of a post-9/11 baby boom and portrayal of Jessica Lynch as a damsel in distress.

The shift in gender politics indicates the deep connections between counterterrorist politics and the so-called "culture wars." Michael Sherry proposed in the mid-1990s that the shift in direction of militarist rhetoric from toward Communists to domestic advocacy groups indicated an inward turn (502). Recognition of counterterrorist gender politics leads to an alternative explanation that the domestic/foreign or inward/outward fell with the Berlin Wall. The threat of terrorist attacks originating in the "homeland" justified proposals for increased military presence in domestic civil society, but these threats' ties to images of international terrorism, implied in a remark by Lewis "Scooter" Libby about attacks of "ambiguous" origin (Libby 307 ), signal the end of the internal/external dichotomy hinged at the border. In context of the culture wars, the counterterrorist response to feminism came with similar repugnance to LGBT advocacy.

The interrelation of the fraught permeability of geographical borders and a shift in negative stereotypes of gay men indicates the role of anxieties about physical penetration. During the "Lavender Scare" of the McCarthy era, homosexuals were depicted as vulnerable to Soviet corruption, particularly as their taboo sexuality rendered them susceptible to blackmail. They were the weak link in the national chain. During the "Don't Ask, Don't Tell" debates in the early 1990s, however, the male homosexual embodied the threat of penetration instead of passivity. Opponents of allowing lesbians and gays to serve openly in the military panicked about straight soldiers having to shower under the gaze of gay men (Sherry 488). Clancy, meanwhile, anxiously gestured at anal penetration when he notes that the terrorists weaponize the Ebola virus with the addition of genes from colon cancer (Clancy 125-26). The only gay character in his narrative is a German terrorist. Where the racial civil rights movement had capitalized on African-Americans' history of military service to demand their rightful place in the American polity, American LGBT individuals were excluded (Sherry 490). Indpendence Day similarly kills off the human characters who have been coded as gay, leaving a cohort of hyper-masculine warriors to fight the sexually ambiguous aliens. 
"Don't Ask, Don't Tell" drew a non-geographical border through American society. The refiguration of the negative stereotype of the homosexual male reflects how the rise of non-statism moved the locus of conflict from national borders to the less geographic social space within the nation. The gay rights movement may have unfortunately coincided with heightened penetration anxieties of bodies that, without national borders, sensed their exposure to the globe. After September $11^{\text {th }}$, this anxiety played out in what Jasbir Puar describes as the "queering" of the terrorist.

The counterterrorist brand of homophobia draws attention to the counterterrorist's sadistic practices against other bodies. In one disturbing scene in Rainbow Six that works through race and sexuality, the two lead counterterrorist heroes, John Clark and Domingo Chavez, torture a terrorist, Timmy. The interaction revolves around Chavez's threat to sever Timmy's penis (661-63). Chavez's race plays a key role because his Latino background makes him inscrutable and unpredictable for an Irish terrorist, so the latter believes the threat might come true (Id.). Meanwhile, Chavez invokes transsexuality by terming phallic amputation a "sex-change operation" (Id.). He justifies this punishment by reminding himself that this terrorist kidnapped his pregnant wife (Id.). The terrorist misappropriation of phallic power, represented in the specter of rape, becomes the basis for a sexualized talionic justice. In the preceding scene, the counterterrorists take advantage of a terrorist in a post-anesthesia "suggestive state" to penetrate his mind for information, explicitly acknowledging that this information is legally useless (659-60). These scenes of terrorist vulnerability before counterterrorist power display the dynamics of extralegal practices.

The escape from legal strictures into non-state spaces is the heart of counterterrorist fantasy. Judith Butler describes the War on Terror, particularly extralegal detention practices, as a situation in which "petty sovereigns abound... delegated with the power to render unilateral decisions, accountable to no law and without any legitimate authority" (56). Independence Day stages the destruction of American political institutions, reducing the government to the pure executive power of the president-situated at the ultimate black site, Area 51. Butler's focus on Guatanamo Bay, a stateless netherworld similar to the apocryphal Area 51, indicates how non-state spaces allow for extralegal responses, where the counterterrorist mirrors the terrorist's arrogation of the decision of who lives and who dies. Perhaps an exchange from Rainbow Six best sums up counterterrorist mirroring. Two counterterrorists are discussing a fictional hijacking that occurred on an Ethiopian Airlines flight. After the hijackers had been restrained, the security forces slit their throats. The counterterrorists approve of the "simple, but effective" action because "nobody had messed with that airline since." The violence served no safety purpose, but was intended to send a message.

Clancy's counterterrorist fantasy and Independence Day's exuberant extralegalism did not exist in a vacuum in the 1990s. In a 1998 article, three prominent neoconservatives directly linked Clancy's fiction to their concerns about WMD terrorism, writing that "long part of the Hollywood and Tom Clancy repertory of nightmarish scenarios, catastrophic terrorism has moved from far-fetched horror to a contingency that could happen next month" (Carter, Deutch, and Zelikow 80). The predicted that "an act of catastrophic terrorism would be a watershed even in American history" which would, "like Pearl Harbor, ...would divide our past and future into a before and after" 
(Id.). Just two years later, The Project for the New American Century published its report Rebuilding America's Defenses, in which the authors contemplate how "the process of transformation" of the military in the fashion favored by neoconservatives "is likely to be a long one, absent some catastrophic and catalyzing event-like a new Pearl Harbor" (Donnelly 51). American analysts had not only fantasized about extralegal counterterrorist practices, they even anticipated the before and after dichotomization of history around the event of catastrophic terrorism. They appear to have shoehorned September $11^{\text {th }}$, which was not a WMD terrorist attack, into a pre-existing narrative. Recognition of the American cultural and political prehistory of the War on Terror points to the disturbing possibility that the acceptance of extralegal tactics was not a decision under duress but the enactment of longstanding counterterrorist fantasies in a culture poised to respond to the events of September $11^{\text {th }}, 2001$, in a particular and problematic fashion.

${ }^{1}$ See Franklin, War Stars, for a discussion of how technology changed the geographical ontology of warfare.

${ }^{2}$ As epitomized in the title of Roberts' article, "Terrorism and Weapons of Mass

Destruction: Has the Taboo Been Broken?"

\section{Works Cited}

Baudrillard, Jean. The Spirit of Terrorism ; and, Other Essays. New ed. London ; New York: Verso, 2003. Print.

Berger, Sandy R. "A Foreign Policy for the Global Age." Foreign Affairs 796 (2000): 2239. Print.

Burleigh, Michael. Blood and Rage : A Cultural History of Terrorism. London: HarperPress, 2008. Print.

Butler, Judith. Precarious Life : The Powers of Mourning and Violence. London; New York: Verso, 2006. Print.

Cameron, Gavin. Nuclear Terrorism : A Threat Assessment for the 21st Century. New York: St. Martin's Press, 1999. Print.

Carter, Andrew, John Deutch, and Philip Zelikow. "Catastrophic Terrorism - Tackling the New Danger." Foreign Affairs 776 (1998): 80-94. Print.

Carus, W. Seth. "The Rajneeshees (1984)." Toxic Terror : Assessing Terrorist Use of Chemical and Biological Weapons. Ed. Tucker, Jonathan B. Bcsia Studies in International Security. Cambridge, Mass.: MIT Press, 2000. 115-37. Print.

Cavarero, Adriana. Horrorism : Naming Contemporary Violence. New Directions in Critical Theory. New York: Columbia University Press, 2009. Print.

Clancy, Tom. Rainbow Six. New York, NY: Berkley Books, 1998. Print.

Cronin, Audrey Kurth. "What is Really Changing? Change and Continuity in Global Terrorism." The Changing Character of War. Eds. Strachan, Hew and Sibylle Scheipers. New York: Oxford University Press, 2011. Print.

Deutch, John. "Terrorism." Foreign Policy 108 (1997): 10-22. Print. 
Donnelly, Thomas, et al. Rebuilding America's Defenses Strategy, Forces and Resources for a New Century : A Report of the Project for the New American Century. 2000. $<$ http://www.newamericancentury.org/RebuildingAmericasDefenses.pdf $>$. Emmerich, Roland. Indpendence Day. Perf. Jeff Goldblum, Will Smith, Vivica A. Fox, Harry Connick Jr, Bill Pullman. MPEG-4 video file. Twentieth Century Fox, 1996.

Falkenrath, Richard A. "Problems of Preparedness - Us Readiness for a Domestic Terrorist Attack." International Security 254 (2001): 147-86. Print.

Faludi, Susan. The Terror Dream : Fear and Fantasy in Post-9/11 America. 1st ed. New York: Metropolitan Books, 2007. Print.

Flynn, Kevin, and Gary Gerhardt. The Silent Brotherhood : Inside America's Racist Underground. New York: Free Press, 1989. Print.

Franklin, H. Bruce. War Stars: The Superweapon and the American Imagination. Rev. and expanded ed. Amherst: University of Massachusetts Press, 2008. Print.

Gibson, James William. Warrior Dreams : Paramilitary Culture in Post-Vietnam America. 1st ed. New York: Hill and Wang, 1994. Print.

Hamm, Mark S. Terrorism as Crime : From Oklahoma City to Al-Qaeda and Beyond. New York: New York University Press, 2007. Print.

Hoffman, Bruce. Inside Terrorism. Rev. and expanded ed. New York: Columbia University Press, 2006. Print.

Johnson, David K. The Lavender Scare : The Cold War Persecution of Gays and Lesbians in the Federal Government. Chicago: University of Chicago Press, 2004. Print.

Kaplan, David E. "Aum Shinrikyo (1995)." Toxic Terror : Assessing Terrorist Use of Chemical and Biological Weapons. Ed. Tucker, Jonathan B. Bcsia Studies in International Security. Cambridge, Mass.: MIT Press, 2000. 207-26. Print.

Laqueur, Walter. "Postmodern Terrorism." Foreign Affairs 755 (1996): 24-36. Print.

Libby, Lewis. "Legal Authority for a Domestic Military Role in Homeland Defense." The New Terror : Facing the Threat of Biological and Chemical Weapons. Eds. Drell, Sidney D., Abraham D. Sofaer and George D. Wilson. Hoover National Security Forum Series. Stanford, Calif.: Hoover Institution Press, 1999. 305 - 27. Print.

Lifton, Robert Jay. Superpower Syndrome : America's Apocalyptic Confrontation with the World. New York: Thunder's Mouth Press/Nation Books, 2003. Print.

Lodal, Jan. The Price of Dominance : The New Weapons of Mass Destruction and Their Challenge to American Leadership. New York: Council on Foreign Relations Press, 2001. Print.

Macdonald, Andrew (pseudonym of William L. Pierce). The Turner Diaries. Arlington, VA: National Vanguard Books, 1978 (1980). Print.

May, Elaine Tyler. Homeward Bound : American Families in the Cold War Era. Fully rev. and updated 20th anniversary ed. New York, NY: Basic Books, 2008. Print.

Oehler, Gordon C. "Warning and Detection." The New Terror : Facing the Threat of Biological and Chemical Weapons. Eds. Drell, Sidney D., et al. Hoover National Security Forum Series. Stanford, Calif.: Hoover Institution Press, 1999. 138 - 54. Print. 
Puar, Jasbir K. Terrorist Assemblages : Homonationalism in Queer Times. Next Wave. Durham: Duke University Press, 2007. Print.

Roberts, B. "Terrorism and Weapons of Mass Destruction: Has the Taboo Been Broken?" Politics and the Life Sciences 152 (1996): 216-17. Print.

Rogin, Michael. Independence Day. London: British Film Institute, 1998. Print.

Rogin, Michael Paul. Ronald Reagan, the Movie and Other Episodes in Political Demonology. Berkeley: University of California Press, 1987. Print.

Rose, Gideon. "Review: It Could Happen Here: Facing the New Terrorism." Foreign Affairs 782 (1999): 131-37. Print.

Rosenbaum, David M. "Nuclear Terror." International Security 13 (1977): 140-61. Print. Sherry, Michael S. In the Shadow of War: The United States since the 1930's. New Haven: Yale University Press, 1995. Print.

Simon, Jeffrey D. "Misunderstanding Terrorism." Foreign Policy 67 (1987): 104-20. Print.

Sprinzak, Ehud and Idith Zertal Sprinzak. "Avenging Israel's Blood (1946)." Toxic Terror : Assessing Terrorist Use of Chemical and Biological Weapons. Ed. Tucker, Jonathan B. Bcsia Studies in International Security. Cambridge, Mass.: MIT Press, 2000. 17-41. Print.

Stevens, Jacqueline. Reproducing the State. Princeton, N.J.: Princeton University Presss, 1999.

Tucker, Jonathan B. "Lessons from the Case Studies." Toxic Terror : Assessing Terrorist Use of Chemical and Biological Weapons. Ed. Tucker, Jonathan B. Bcsia Studies in International Security. Cambridge, Mass.: MIT Press, 2000. 24969. Print. 